\title{
Selective concentration and localization of gold in macrophages of synovial and other tissues during and after chrysotherapy in rheumatoid patients
}

\author{
B. VERNON-ROBERTS*, J. L. DORE*, J. D. JESSOP $\dagger$, AND W. J. HENDERSON
} From the Bone and Joint Research Unit, London Hospital;* Department of Rheumatology, University Hospital of Wales $\dagger$; and the Tenovus Institute for Cancer Research, Cardiff $\neq$

\begin{abstract}
Vernon-Roberts, B., Doré, J. L., Jessop, J. D., and Henderson, W. J. (1976). Annals of the Rheumatic Diseases, 35, 477-486. Selective concentration and localization of gold in macrophages of synovial and other tissues during and after chrysotherapy in rheumatoid patients. Gold distribution was studied in the tissues of 7 rheumatoid patients who had died from 0 to 23 years after stopping chrysotherapy (sodium aurothiomalate) and in 23 samples of synovial tissue removed surgically at intervals during chrysotherapy in 5 patients.

After the application of a highly specific staining technique, the cellular localization of gold was examined microscopically in various tissues: the amounts of gold in selected areas of the same specimens which had been examined microscopically were then measured by neutron activation analysis.

During active chrysotherapy gold was abundant in synovial lining cells except where a fibrin layer was present on the surface; after stopping chrysotherapy, gold disappeared from the synovial lining cells. Gold accumulated progressively in the subsynovial connective tissues during chrysotherapy, but was not uniformly distributed, and bore no relationship to fluctuations in serum gold levels. Gold deposition was not confined to joint tissue, but was found within the macrophages of many organs, renal tubular epithelium, and, after recent chrysotherapy, in seminiferous tubules, hepatocytes, and adrenal cortical cells. Gold persisted in synovial and other tissues for up to 23 years after chrysotherapy was stopped.
\end{abstract}

The overall findings indicated that gold is selectively concentrated within inflamed synovial tissues during chrysotherapy.

Although gold salts have been used in the treatment of rheumatoid arthritis for over $\mathbf{4 0}$ years, relatively little is known about the mechanisms whereby they alleviate rheumatoid disease activity. The purpose of this study was to investigate the localization, concentration, and retention of gold (Au) within the cells of synovial and other tissues in rheumatoid patients during and after chrysotherapy, since this could provide information of fundamental importance to the understanding of the mode of action of gold salts.

\section{Materials and methods}

\section{SELECTION OF TISSUES}

Tissues were obtained from 12 cases of rheumatoid arthritis, all of whom had received chrysotherapy at some time during the course of the disease. Brief clinical details of each case are shown in Table I. Synovial tissues were examined from 5 patients before, during, or after chrysotherapy, Synovial and other tissues were obtained at autopsy from 7 patients in whom chrysotherapy was stopped from 0 (receiving sodium aurothiomalate at time of death) to 23 years before death. 
Table I Clinical features of 12 patients examined in the study

\begin{tabular}{|c|c|c|c|c|c|c|c|c|c|c|c|}
\hline \multirow[b]{2}{*}{$\begin{array}{l}\dot{8} \\
\vdots \\
\vdots \\
0\end{array}$} & \multirow[b]{2}{*}{ 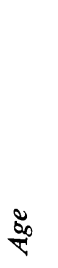 } & \multirow[b]{2}{*}{ ڤัँ } & \multicolumn{4}{|c|}{ Clinical } & \multicolumn{5}{|c|}{ Gold } \\
\hline & & & $\frac{\tilde{d}}{\mathfrak{z}}$ & ڤ్ & 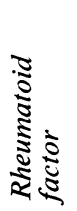 & 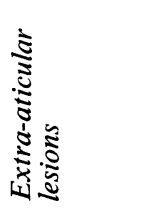 & $\begin{array}{l}\text { ब0 } \\
0 \\
0 \\
0 \\
\vdots \\
0 \\
0\end{array}$ & 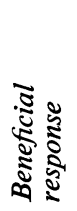 & .స్త్ర & 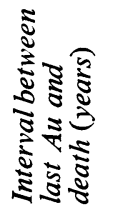 & 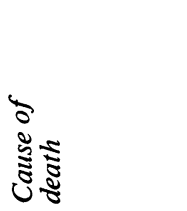 \\
\hline 1 & $50 *$ & $\mathrm{~F}$ & - & + & + & - & $2 \cdot 6^{*}$ & + & - & - & Still alive \\
\hline 2 & $55^{*}$ & $\mathbf{F}$ & + & + & + & 一 & $1 \cdot 4^{*}$ & $?$ & - & - & Still alive \\
\hline 3 & $71 *$ & $F$ & 一 & - & + & - & $1 \cdot 4^{*}$ & 一 & - & 一 & Still alive \\
\hline 4 & $54 *$ & $\mathbf{M}$ & - & - & 一 & 一 & $0 \cdot 7^{*}$ & $?$ & 一 & 一 & Still alive \\
\hline 5 & $47 *$ & $\mathbf{M}$ & 一 & + & + & - . . & $1 \cdot 2^{*}$ & + & 一 & - & Still alive \\
\hline 6 & 65 & $\mathbf{M}$ & + & + & + & Amyloid & $1 \cdot 0$ & $t$ & 一 & 23 & $\begin{array}{l}\text { Reticulum } \\
\text { cell sarcoma }\end{array}$ \\
\hline 7 & 60 & $\mathrm{~F}$ & 一 & + & $\longrightarrow$ & 一 & $0 \cdot 6$ & $?$ & - & 20 & $\begin{array}{l}\text { Analgesic } \\
\text { nephropathy }\end{array}$ \\
\hline 8 & 57 & $\mathrm{M}$ & - & + & - - & - ... & $1 \cdot 0$ & + & 一 & 15 & Haemoptysis \\
\hline 9 & 58 & $\mathbf{M}$ & + & + & + & Arteritis & $0 \cdot 7$ & + & + & 3 & $\begin{array}{l}\text { Broncho- } \\
\text { pneumonia }\end{array}$ \\
\hline 10 & 57 & $\mathrm{~F}$ & + & + & + & $\begin{array}{l}\text { Fibrosing } \\
\text { alveolitis }\end{array}$ & $1 \cdot 0$ & + & + & 3 & $\begin{array}{l}\text { Heart } \\
\text { failure }\end{array}$ \\
\hline 11 & 54 & $F$ & + & + & + & Pericarditis & $0 \cdot 2$ & 一 & + & 2 & Renal failure \\
\hline 12 & 46 & $\mathbf{M}$ & - & 一 & + & $\begin{array}{l}\text { Fibrosing } \\
\text { alveolitis }\end{array}$ & $3 \cdot 5$ & + & - & On gold & $\begin{array}{l}\text { Carcinoma } \\
\text { lung }\end{array}$ \\
\hline
\end{tabular}

*At the time of last synovectomy. $-=$ absent $;+=$ present; $?=$ doubtful.

VISUALIZATION OF Au IN TISSUE SECTIONS

We have evaluated the many methods described for the demonstration of $\mathrm{Au}$ in tissue sections (Doré, 1974), and have found them to be unsatisfactory because of lack of specificity, poor resolution, and technical difficulties with counterstaining procedures. Sections of formalin-fixed paraffin-embedded synovium and other tissues were therefore subjected to a new photochemical technique which shows the presence of gold. The exact details of the technique are described elsewhere (Doré and VernonRoberts, 1976), and the principles of the method are as follows. (1) $5 \mu \mathrm{m}$ sections of tissue are mounted on glass slides; (2) coated with celloidin; (3) immersed in a solution containing a silver complex and exposed to a strong light; (4) washed with distilled water; (5) transferred to a dark room and developed photographically; (6) photographically fixed; (7) removed from the dark room and washed; (8) celloidin removed; (9) counterstained with neutral red and light green; (10) mounted in Canada balsam. This technique shows the presence of $\mathrm{Au}$ as a microscopically visible black reaction product due to the deposition of visible silver on underlying $\mathrm{Au}$ (see below).

SPECIFICITY OF AU STAIN

The specificity of the reaction has been confirmed using electron microscope microanalysis (EMMA). EMMA can specifically detect and localize individual elements from sodium upwards in the periodic table to a limit of $10^{-18} \mathrm{~g}$. In these studies EMMA was applied to normal ultrathin sections (Fig. 1) and to $5 \mu \mathrm{m}$ paraffin sections previously subjected to the Au staining technique after extraction/ replication (Henderson and Griffiths, 1972). This showed that the black reaction product formed after Au staining is the result of the formation of visible silver deposited o⿺辶 underlying intracellular Au (Fig. 2). It has long beef known that treatment with dilute aqueous potassiun cyanide solution removes $\mathrm{Au}$ and its salts from tissue sections by chelation (Christeller, 1927). After Au has been removed by this treatment, the Au staining method used does not show the presence of a visible reaction product. The Au staining method has been applied to tissues containing pigments and other metals and does not give a positive reaction product with lipofuscin, melanin, bile, calcium, iron, cobalt, chromium, and nickel. Tissues from rheumatoid patients who had not received Au treatment at any time did not exhibit positive staining for $\mathrm{Au}$.

NEUTRON ACTIVATION ANALYTICAL STUDIES

After application of the Au staining techniques, sections were examined microscopically to select areas for measurement of tissue Au concentration. The sequence of events was as follows. (1) Sections were examined microscopically for visual assessment of Au concentration; (2) a selected area of the parent block of wax-embedded tissue was excised; (3) excised block of tissue $\left(20-40 \mathrm{~mm}^{3}\right)$ o dewaxed, dried, and accurately weighed; (4) specimen subjected to neutron bombardment converting stable ${ }^{197} \mathrm{Au}$ to radioactive ${ }^{198} \mathrm{Au} ;(5){ }^{198} \mathrm{Au}$ content assessed by $\mathrm{\omega}$ gamma-counting; (6) concentration of $\mathrm{Au}$ in the specimen calculated in parts per million (ppm) on a weightfor-weight basis, the minimum detection level being $0 \cdot 1 \mathrm{ppm}$. All surgical and autopsy tissues which were $\mathbb{O}$ available for microscopy in this retrospective study were ? examined for the presence of $\mathrm{Au}$ using the Au staining technique. Only a small proportion of these tissues were subjected to neutron activation analysis (NAA) because of the very high cost. 

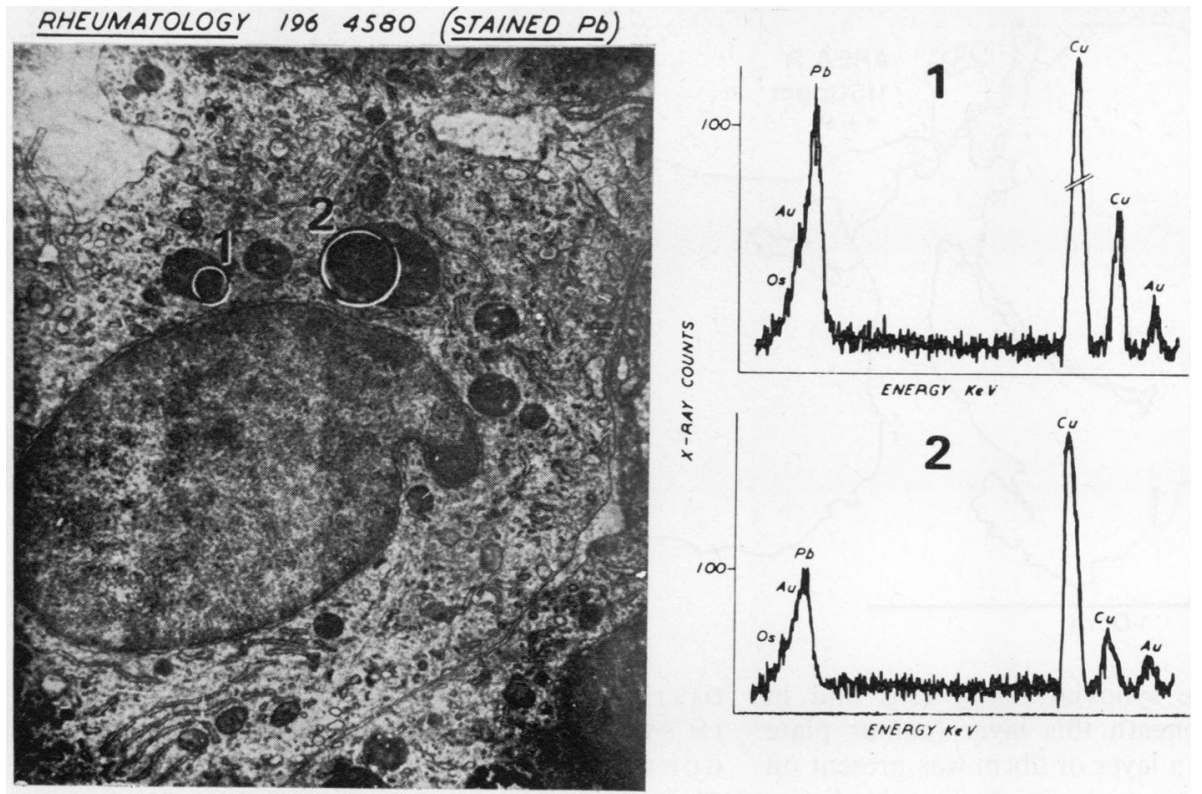

FIG. 1 Electron microscope microanalysis of macrophage in synovial tissue from rheumatoid patient. The electron dense areas in the lysosomes, ringed 1 and 2 in the electron micrograph (left) have been separately analysed (right). The analysis confirms the presence of gold $(A u)$; also present is osmium $(O s)$ which was used as a tissue fixative, lead $(P b)$ used as a issue stain, and copper $(\mathrm{Cu})$ forming the grid supporting the section

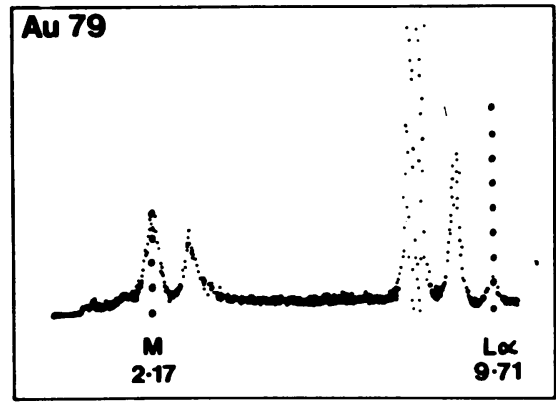

Energy (keV)

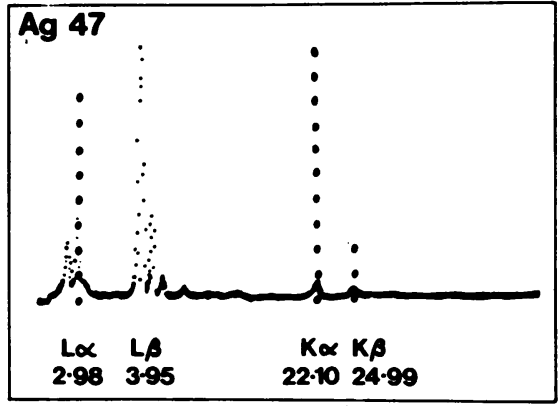

Energy (keV)

FIG. 2 Electron microscope microanalysis of intracellular black reaction product produced by histological staining technique to demonstrate gold. Analysis shows constant association between deposited silver (Ag 47) and intracellular gold $(A u$ 79)

\section{Results}

RELATIONSHIP BETWEEN LOCALIZATION AND CONCENTRATION OF Au IN DIFFERENT AREAS OF SYNOVIAL TISSUE

Early in the course of microscopical examination of tissues subjected to the $\mathrm{Au}$ staining technique it became apparent that there were considerable variations in the amount of intracellular Au present in different areas of synovial tissues, and this was confirmed by the results of NAA. This is exemplified by reference to our findings in Case 1. An outline map of one of the sections of synovial tissue from this patient is shown in Fig. 3a: it can be seen that area $\mathbf{A}$ of the section contained abundant intracellular $\mathrm{Au}$ and had an $\mathrm{Au}$ content of $1150 \mathrm{ppm}$ (colour plate $3 \mathrm{~b}$ ), whereas area B contained relatively little intracellular Au (colour plate 3c), and had an Au content of $175 \mathrm{ppm}$.

The results overall indicated that, in general, the joint affected by rheumatoid arthritis in patients currently receiving chrysotherapy tended to have 


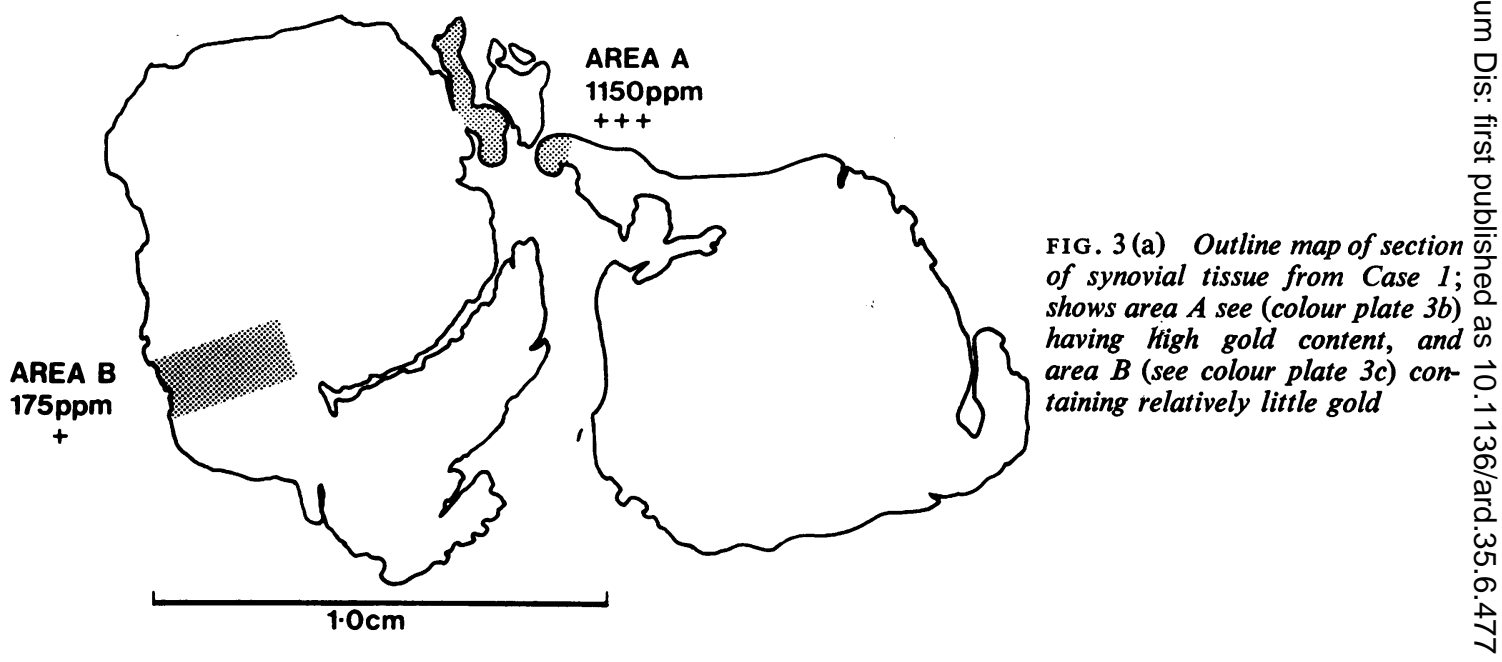

abundant $\mathrm{Au}$ in the synovial lining cells and in macrophages just beneath this layer (colour plate 4). In contrast, when a layer of fibrin was present on the surface of the synovial membrane, the lining cells contained little or no Au (colour plate 5). In patients not currently receiving chrysotherapy there was little or no Au in the lining layer. In the presence or absence of surface fibrin, increasing numbers of macrophages containing abundant $\mathrm{Au}$ became focally concentrated around small blood vessels in the deeper connective tissues of the synovium during chrysotherapy, and continued to be present at these sites after the stopping chrysotherapy.

The Au content of various tissues measured by NAA are quoted in the results as the mean for each tissue, but we must emphasize that these figures have little relevance to the location of cells containing $\mathrm{Au}$ in the tissues analysed.
DISTRIBUTION AND CONCENTRATION OF Au IN SYNOVIAL TISSUES IN PATIENTS UNDERGOING REPEATED SYNOVECTOMY

The distribution and concentration of $\mathrm{Au}$ was examined in the synovial tissues from 4 patients who underwent repeated synovectomy. The time relationship between the start of chrysotherapy an $8 \vec{\sigma}$ synovectomy, total dose of sodium aurothiomalate oे (SATM) at the time of synovectomy, and the cone. centration of $\mathrm{Au}$ in the synovial tissue measured b NAA in each case is shown in Table II.

In Cases 2 and 3 about 2 years had elapsed between the start of chrysotherapy and the first synovectomy; both had received a total of $1.4 \mathrm{~g}$ SATM. The mean synovial tissue level of Au was $600 \mathrm{ppm}$ in Case 2 who was receiving chrysotherapy until just before operation, whereas the synovial tissue Au concentration was $320 \mathrm{ppm}$ in Case 3 who had stopped

Table II Total dose of sodium aurothiomalate and synovial gold concentration in 4 patients undergoing repeated synovectomy

Time between first injection of sodium aurothiomalate and synovectomy

(m)

Case 2
1st operation
2nd ,"
Case 3
1st operation
2nd ",
Case 4
1st operation
2nd ",
Case 5 ",
1st operation
2nd ",
3rd ",
4th ",

\begin{tabular}{|c|c|}
\hline $\begin{array}{l}\text { Total sodium } \\
\text { aurothiomalate } \\
\text { administered } \\
\text { before synovectomy } \\
(\mathrm{g})\end{array}$ & $\begin{array}{l}\text { Synovial sodium } \\
\text { aurothiomalate } \\
\text { concentration } \\
(p p m)\end{array}$ \\
\hline $\begin{array}{l}1.4 \\
1.4\end{array}$ & $\begin{array}{l}600 \\
200\end{array}$ \\
\hline $\begin{array}{l}1.4 \\
1.4\end{array}$ & $\begin{array}{r}320 \\
30\end{array}$ \\
\hline $\begin{array}{r}0 \\
0.7\end{array}$ & $\begin{array}{r}0 \\
4000\end{array}$ \\
\hline $\begin{array}{r}0 \\
0 \cdot 7 \\
0 \cdot 9 \\
1 \cdot 2\end{array}$ & $\begin{array}{r}0 \\
700 \\
200 \\
50\end{array}$ \\
\hline
\end{tabular}




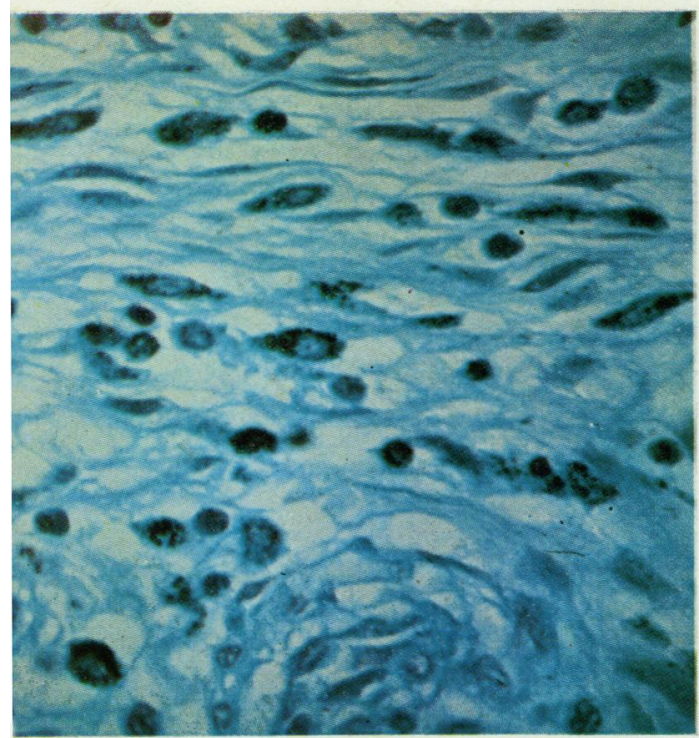

(3b)

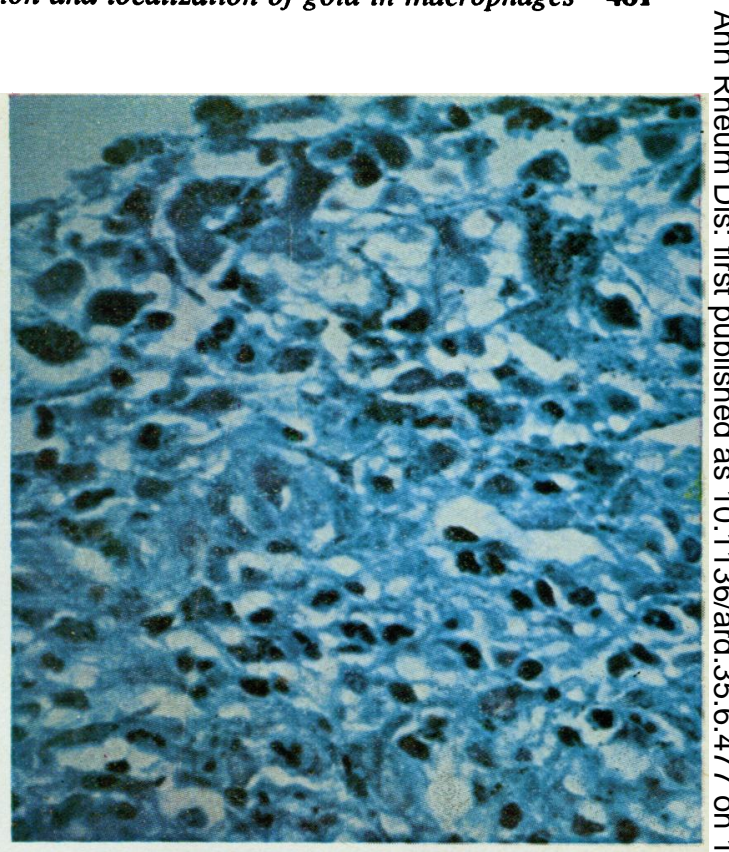

$(3 c)$

COLOUR PLATE 3(b) Case 1. Area A from Fig. 3a showing abundant gold-containing macrophages within the synovial connective issues. $\times 600$. (c) Case 1. Area B from Fig. 3a showing moderate amount of gold largely confined to synovial lining cells. $\times 600$

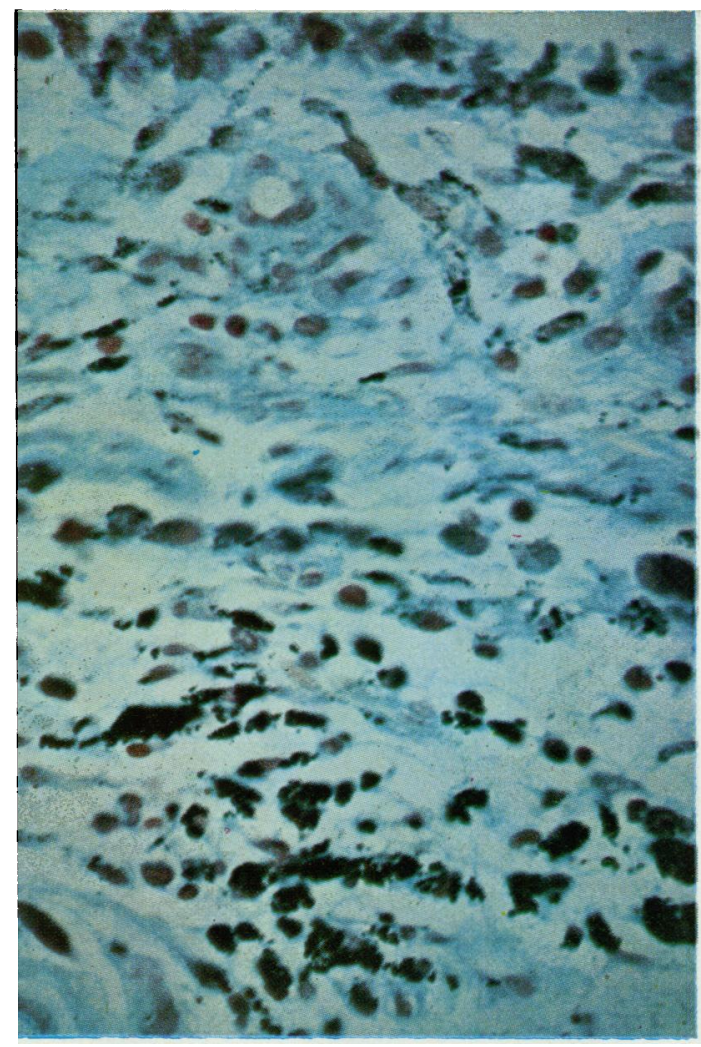

(4)
COLOUR PLATE 4 Case 4. Currently receiving chrysotherapy (total dose $0.7 \mathrm{~g}$ sodium aurothiomalate). There abundant gold in the synovial lining cells and macrophagess of the underlying connective tissues. $\times 600$ COLOUR PLATE 5 Case 1. Currently receiving chryso therapy (total dose $2.2 \mathrm{~g}$ sodium aurothiomalate). Gold is absent from the synovial lining cells underlying a thin layer of surface fibrin. $\times 600$

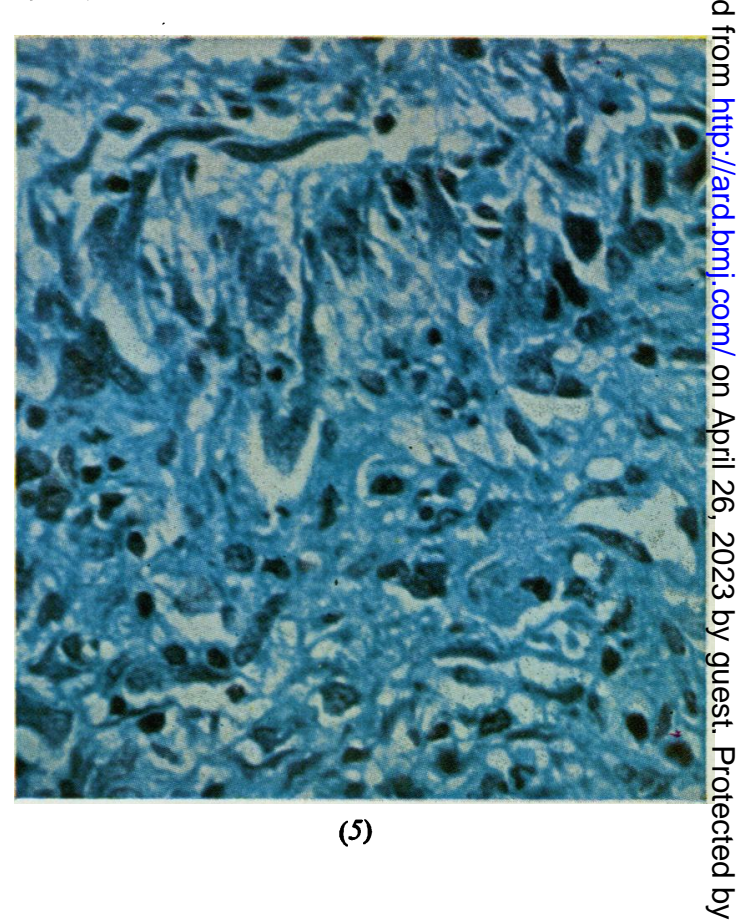


receiving SATM 8 months before the operation. Both patients had second synovectomies 6 months later and had not received further chrysotherapy in the intervening period; at this time the mean synovial Au level was $200 \mathrm{ppm}$ in Case 2 and $30 \mathrm{ppm}$ in Case 3. The findings in Cases 2 and 3 indicated that there was a progressive loss of $\mathrm{Au}$ from the synovial tissue after stopping chrysotherapy.

Case 4 had undergone synovectomy before starting chrysotherapy, and the analytical findings confirmed the absence of Au. Synovectomy was performed 4 months after starting chrysotherapy, when the patient had received a total dose of $0.7 \mathrm{~g}$ SATM: the operation was performed 40 minutes after intramuscular injection of $50 \mathrm{mg}$ SATM. The synovial tissues contained the exceptionally high level of $4000 \mathrm{ppm} \mathrm{Au}$, but microscopical examination after the gold stain showed that $\mathrm{Au}$ was largely restricted to the intimal layer and the cells just deep to this layer. These findings suggested that the $\mathrm{Au}$ concentration was largely reflecting the very high serum levels which would be present at this time.

Case 5 underwent 4 synovectomies, the first of which preceded chrysotherapy. The synovial Au level was $700 \mathrm{ppm} 7$ months after starting chrysotherapy (total dose $0.7 \mathrm{~g}$ SATM); 5 months later, while receiving monthly $50 \mathrm{mg}$ SATM injections, the synovial level had fallen to $200 \mathrm{ppm}$; 1 year later, having received but 5 further injections at irregular intervals, the tissue Au level had fallen to $50 \mathrm{ppm}$. Microscopical examination of the same tissues after

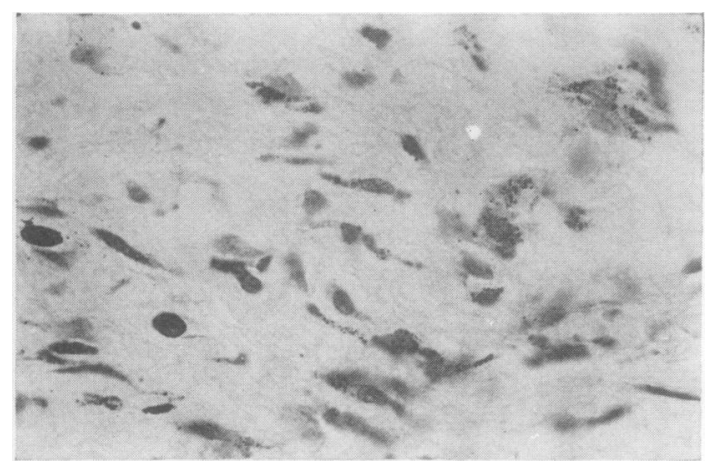

FIG. 6 (a) Case 5.7 months after starting chrysotherapy (total dose $0.7 \mathrm{~g}$ sodium aurothiomalate). Macrophages of the synovial connective tissue contain abundant gold. $\times 350$. (b) Case 5.12 months after starting chrysotherapy (total dose $0.9 \mathrm{~g}$ sodium aurothiomalate). Abundant gold is still present in the macrophages of the synovial tissue despite the marked fall in overall synovial tissue gold concentration and serum gold levels shown in 6a. $\times 350$. (c) Case 5 . Receiving sodium aurothiomalate irregularly. Shows that tissue gold concentration (black columns) diminishes as the serum gold level (broken line) falls. Arrows indicate injections of $50 \mathrm{mg}$ sodium aurothiomalate
Au staining showed that the decreasing concentra tions of $\mathrm{Au}$ were associated with a progressive? diminution in the amounts of $\mathrm{Au}$ present in the? lining cells and just deep to this layer, and the्छ accumulation of Au-containing cells in the deeper connective tissues (Figs. 6a, b). When the overalE tissue $\mathrm{Au}$ concentrations were examined in relation to serum $\mathrm{Au}$ levels (Fig. 6c), it was found that ${ }_{\mathbb{D}}$ despite histological evidence of increasing Auf accumulation in the deep connective tissues (Figs? $6 a, b)$, the decreasing tissue $\mathrm{Au}$ concentration $\vec{D}$ appeared to follow a similar decline to that in serum $\mathrm{Au}$ concentration. This indicated that duringw chrysotherapy overall tissue $\mathrm{Au}$ concentration largely reflects changes in serum $\mathrm{Au}$ concen? tration, and may obscure an increase or decrease of intracellular $\mathrm{Au}$ in different compartments of the synovial tissue.

The findings in these serial synovectomy specimens confirmed that high concentrations of Au are present in the surface layers of the synovial tissue $\vec{b}$ during chrysotherapy, but progressively diminisho after chrysotherapy is stopped. They also confirmedo

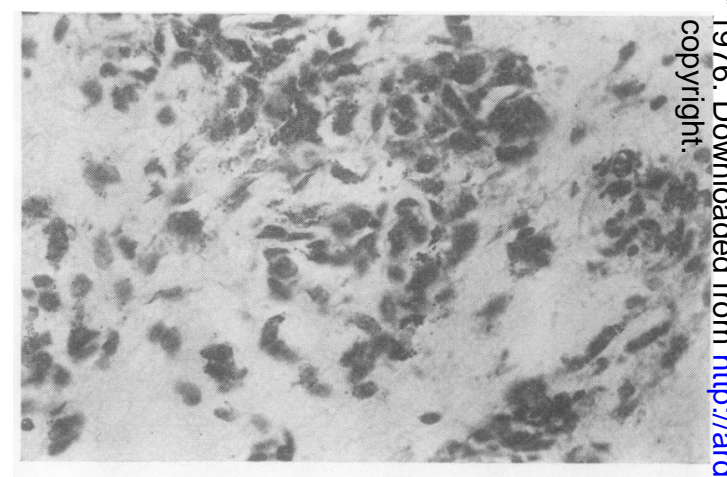

(b)

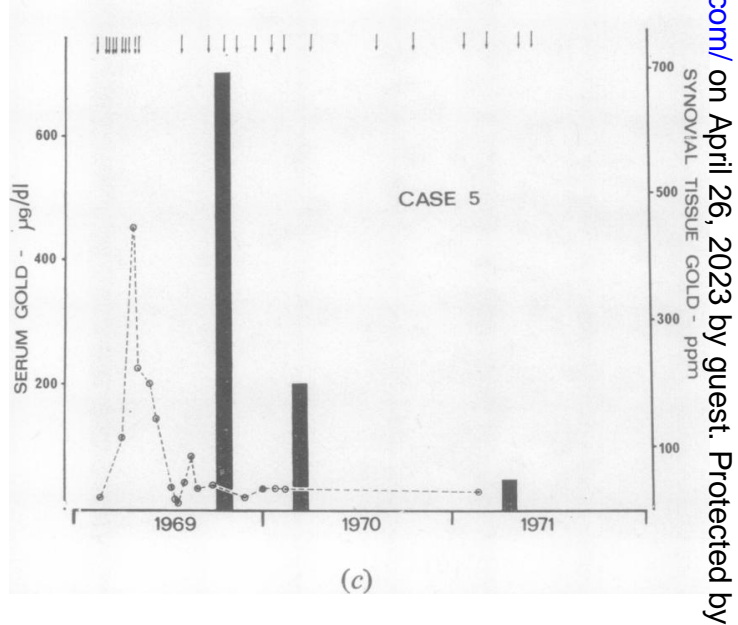


that increasing numbers of Au-containing macrophages accumulate in the deeper synovial tissues during chrysotherapy. During chrysotherapy the total $\mathrm{Au}$ concentration appears to largely reflect the current serum Au level.

CONCENTRATION AND LOCALIZATION OF AU IN SYNOVIAL AND OTHER TISSUES DURING AND AFTER CHRYSOTHERAPY

The concentration and localization of $\mathrm{Au}$ was examined in joints and other tissues obtained at autopsy from rheumatoid subjects who had stopped receiving chrysotherapy from 2 to 23 years before death; from 1 subject who was receiving chrysotherapy at death, and from 1 who had not received treatment with Au salts at any time during the course of the disease. Brief clinical details of the 7 test cases are given in Table $\mathbf{I}$.

In each case all the tissues taken at autopsy were subjected to Au staining, but because of the high cost, only a small proportion of the tissues available were subjected to NAA. Moreover, since this was a retrospective study some tissues which would have been of interest were absent in some cases (TableIII). The tissues analysed for Au content by NAA are listed in Table III, which shows that Au persisted in synovium, kidney, liver, spleen, marrow, lymph nodes, skin, gonad, adrenal, and lung in variable amounts up to 23 years after chrysotherapy was stopped; the tissue $\mathrm{Au}$ levels in the patient on chrysotherapy at the time of death were generally much higher than in those in whom chrysotherapy was stopped.

The findings overall showed that, in general, the largest amounts of $\mathrm{Au}$ were retained in the adrenal, testis, synovial tissues (showing evidence of involvement by rheumatoid disease), kidney, and lymph nodes; and lesser amounts in the liver, spleen, marrow, skin, and lung. There was no clear relationship between the amounts of Au persisting in a particular tissue and the total dose of gold administered or the time elapsed since stopping chrysotherapy.

Microscopical examination of various tissues provided the following information in each case.

\section{Synovium}

In agreement with our findings in surgical synovectomy specimens the synovial tissue of the patient receiving chrysotherapy at the time of death (Case 2) showed abundant Au in the surface layers of the synovial tissues. In contrast, in the other cases Au was absent from the surface layers but was present in macrophages generally grouped around small blood vessels in the deeper connective tissues. Joints which had no clinical or pathological evidence of involvement by rheumatoid disease at any time contained little or no visible $\mathrm{Au}$, whereas $\mathrm{Au}$ was constantly present in the synovium and pannus of affected joints, and was most abundant in joints exhibiting active disease.

\section{Kidney}

The majority of $\mathrm{Au}$ in the kidney was present in the proximal tubular epithelium. Variable amounts, usually small, were present in the distal tubular epithelium, interstital cells, glomerular mesangium, Bowman's capsule, and pelvic epithelium.

\section{Liver}

In the patient receiving $\mathrm{Au}$ at the time of death, some $\mathrm{Au}$ was visible within hepatocytes, but the majority of $\mathrm{Au}$ in this and other cases was confined to macrophages lining sinusoids (Kupffer cells) and portal tracts.

Table II Gold concentrations in various tissues from 7 patients dying at intervals of up to 23 years after stopping chrysotherapy

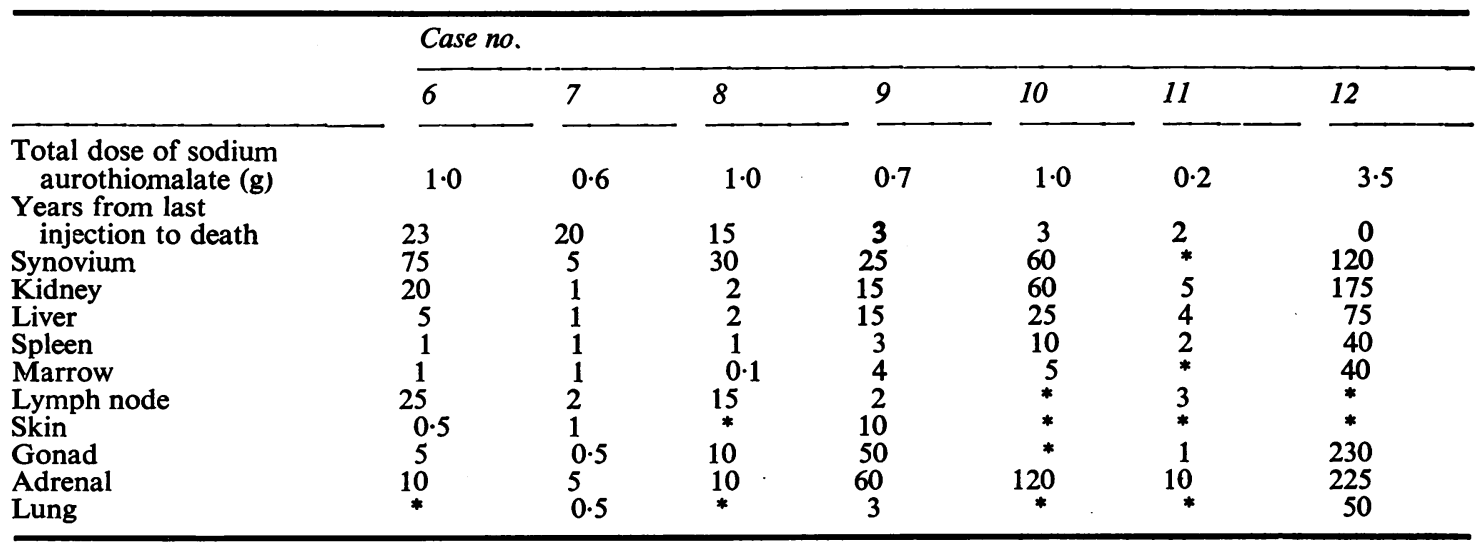

* Not available for analysis. 


\section{Spleen}

Au was confined to occasional macrophages in the marginal zones around the white pulp and in the red pulp.

\section{Marrow}

$\mathrm{Au}$ was present in mononuclear cells having the appearance of fixed mononuclear phagocytes. In the patient receiving chrysotherapy at the time of death numerous fine granules of $\mathrm{Au}$ were present in megakaryocytes and granulocytes.

\section{Lymph nodes}

$\mathrm{Au}$ was present in macrophages lining subcapsular sinuses, sinuses of the medullary pulp, and occasional macrophages in primary follicles and germinal centres.

\section{Skin}

$\mathrm{Au}$ was present in macrophages around small vessels in the connective tissue of the dermis and in stellate macrophages of adipose tissue.

\section{Gonad}

In the patient receiving $\mathrm{Au}$ at the time of death, abundant Au was present in the seminiferous epithelium of the testis and in macrophages of the interstitial tissues. After chrysotherapy, $\mathrm{Au}$ was confined to macrophages in the interstitial cells of the testis or the stroma of the ovary.

\section{Adrenal}

In the patient receiving $\mathrm{Au}$ at the time of death large amounts of $\mathrm{Au}$ were present in the zona glomerulosa and in macrophages lining the sinuses. After chrysotherapy, many macrophages lining the sinuses contained abundant $\mathrm{Au}$, but some fine granules persisted in the zona glomerulosa.

\section{Lung}

It was not possible to distinguish the black reaction product of the Au stain from the carbon normally present in lung macrophages.

\section{Other tissues}

Au was constantly present in variable numbers of round, spindle, and stellate macrophages in the connective tissues of joint capsule, skeletal, cardiac, and smooth muscle, alimentary tract, salivary glands, lacrimal glands, endocrine glands, prostate, blood vessels, and serous membranes. There was no definite evidence of $\mathrm{Au}$ being present in cells other than macrophages in these tissues. Au was absent from the matrix of cartilage and bone.

\section{Rheumatoid nodule}

Variable amounts of Au were present in the pallisading macrophages around the central, Au-free, necrotic areas of rheumatoid nodules.

\section{Discussion}

This correlated microscopical and analytical study $\underset{\sim}{\circ}$ of $\mathrm{Au}$ localization and concentration in rheumatoid patients receiving chrysotherapy has shown that $\mathrm{Au}_{\stackrel{S}{\leftrightarrows}}$ is present in synovial tissues affected by rheumatoido disease, and that little or no $\mathrm{Au}$ is present in joints not affected by the inflammatory process at any $\frac{\bar{\rho}}{\overrightarrow{ }}$ time. Our findings agree with those of Lawrence $\stackrel{\square}{\varrho}$ (1961), who measured the distribution of ${ }^{198} \mathrm{Au}-\stackrel{\mathrm{c}}{\mathrm{\omega}}$ SATM in 5 rheumatoid subjects and found that significantly higher amounts of Au were concentrated ${ }_{-}^{\circ}$ in painful joints than in the symptomless joints $\vec{\omega}$ which did not appear to differ appreciably from nonarticular zones of the limbs. Our findings also agree with the spectrophotometric studies in $16 \omega$ patients by Grahame and others (1974) that there $e_{0}^{\text {G }}$ was selective deposition of $\mathrm{Au}$ in the synovialit tissues during 'active' chrysotherapy. However, $\checkmark$ Gottlieb, Smith, and Smith (1972) interpreted the results of NAA of $\mathrm{Au}$ distribution in a singlerheumatoid patient who had received $5 \mathrm{~g}$ aurothioglucose, as showing that comparatively low concentrations were present in articular tissues. Our studies show Au levels which reflect concentrations of gold in the blood and body fluids; this suggests that studies involving determination of tissue puy levels during chrysotherapy have little relevance $0_{0}^{\circ}$ the concentration and distribution of $\mathrm{Au}$ at intracellular level. Since the patient examined bys Gottlieb and others had received an injection of aurothioglucose only 8 weeks before death, and noo histological assessment of Au distribution was made,, no conclusions could be made regarding the true cellular Au concentration in relation to inflammatory 3 activity in various areas of the joint tissue analysed?

In patients receiving Au salts at the time of exam? ination of the synovial tissues, Au was present inw high concentrations in the synovial cells lining the joint, and in macrophages just deep to this layer $\frac{}{3}$ This is in agreement with the ultrastructural studiesn. of Norton, Lewis, and Ziff (1968), who found eleco을 tron dense deposits characteristic of $\mathrm{Au}$ within synovial lining cells and in mononuclear cells of the underlying subsynovial tissues in 5 patients who had received recent intra-articular SATM. However, we found that where fibrin was present on the surface of the synovial membrane the lining cells and under lying macrophages contained little visible $\mathrm{Au}$. When combined with the fact that little or no $\mathrm{Au}$ was ob served in the lining cells in patients not currently re? ceiving chrysotherapy, our findings indicate that the $\mathrm{Au}$ in lining cells is the result of uptake of Au directlo from the synovial fluid. In this connection it is known that there is a rapid equilibration of $\mathrm{Au}$ in serum? and synovial fluid after injection of SATM (Gerbe ${ }_{D}$ and others, 1972). The findings also indicate that the $\mathrm{Au}$ present in the macrophages immediately deep 
to this lining is also obtained directly from the synovial fluid by a similar mechanism as described by Ziff (1964) for the passage of intra-articularlyinjected colloidal Au between lining cells.

During chrysotherapy $\mathrm{Au}$ accumulated in the connective tissues of the synovial membrane as coarse and fine intracellular deposits within macrophages predominantly located around small blood vessels. Our findings suggested that $\mathrm{Au}$ was entering the tissues from the blood vessels at these sites. It was not possible to ascertain how much of this $\mathrm{Au}$ entered the tissues within immigrant inflammatory cells, or as protein-bound $\mathrm{Au}$ in inflammatory fluid exudates. In this perivascular situation, the Au-containing cells persist in variable numbers for at least 23 years after stopping chrysotherapy.

Although Au persists in the joints for a very long period of time after chrysotherapy is stopped, our serial synovectomy studies show that, after stopping treatment there is at least an initial reduction of $\mathrm{Au}$ concentrations in joint tissue. This may reflect the loss of $\mathrm{Au}$ from the lining cells which contain large amounts during active treatment, but the histological evidence suggested the possibility that some Au-containing lining cells migrated into the deeper subintimal tissues.

During or after chrysotherapy there was no histological evidence that the intracellular deposits were toxic to the macrophages which contained them. Moreover, while there was no definite evidence that cells released $\mathrm{Au}$ to be rephagocytosed by a decreasing population of macrophages, this might be inferred by the presence of fewer cells containing larger amounts of $\mathrm{Au}$ in the subsynovial connective tissues. This agrees with the current evidence that in chronic inflammatory lesions there is a progressive increase in the preponderance of long-lived macrophages containing abundant phagocytosed material, and the progressive disappearance of macrophages containing little phagocytosed material (Spector, 1969).

Recent studies have ascribed a key role for the macrophages in rheumatoid synovial tissues in the erosive process of bone and cartilage (Poole and others, 1974). Our findings that the macrophages of the synovial tissues not only concentrate $\mathrm{Au}$, but also retain a proportion after therapy has stopped, support the concept that the beneficial therapeutic effects of $\mathrm{Au}$ salts are mediated through their action on macrophages. In this connection there is evidence showing that Au salts not only suppress the activity of lysosomal enzymes of macrophages (Persellin and Ziff, 1966), but also suppress the phagocytic activity of macrophages in rheumatoid patients (Jessop, Vernon-Roberts, and Harris, 1973).

In agreement with the analytical findings of others (Lawrence, 1961 ; Gottlieb and others, 1972) we have found that Au becomes widely distributed throughout the body. Our studies showed that in patients who have received chrysotherapy at some time during the course of rheumatoid disease $\mathrm{Au}$ becomes located within 'fixed' macrophages throughout the organs and tissues of the body. Some Au is also retained in significant amounts in the proximal tubular epithelium of the kidney; this observation is probably related to the passage of $\mathrm{Au}$ bound to serum protein, through the glomerulus and its subsequent reabsorption in the proximal tubular epithelium (Strunk and Ziff, 1970; Silverberg and others, 1970; Ganote, Beaver, and Moses, 1966).

In the patient receiving chrysotherapy at the time of death, in addition to Au being present in joint and tissue macrophages and in the kidney, Au was also present in hepatocytes, glomerular cells of the adrenal cortex, seminiferous epithelium of the testis, and in megakaryocytes and neutrophil polymorphs of the bone marrow. The possible therapeutic or toxic role of $\mathrm{Au}$ present in these extra-articular tissues remains speculative, but it is possible that $\mathrm{Au}$ enters these cells as a by-product of normal protein incorporation without apparently influencing their functional activity. This aspect of Au localization clearly requires further investigation.

We are grateful for financial support from the Arthritis and Rheumatism Council and the Tenovus Organization. We are grateful to Mr. L. Salmon of the Environmental and Medical Sciences Division, AERE Harwell, for performing neutron activation analysis.

\section{References}

Christeller, E. (1927) Verh. dtsch. Ges. Path., 22, 173 (Ein microchemischer Goldnachweis im Gwebe)

DoRÉ, J. L. (1974) 'The demonstration and distribution of gold in tissue sections'. Thesis for Diplomate Fellowship to the Institute of Medical Laboratory Sciences, London

- _ AND VeRNON-RoBERTS, B. (1976) Med. lab. Sci. 33, 209 (A method for the selective demonstration of gold in tissue sections)

Ganote, C. E., Beaver, D. L., ANd Moses, H. L. (1966) Arch. Path., 81, 429 (Renal gold inclusions)

Gerber, R. C., PAulus, H. E., Bluestone, R., AND LeDERER, M. (1972) Arthr. and Rheum., 15, 625 (Kinetics of aurothiomalate in serum and synovial fluid)

GotTlieb, N. L., SmIth, P. E., AND SmIth, E. M. (1972) Ibid., 15, 16 (Tissue gold concentration in a rheumatoid arthritic receiving chrysotherapy) 
Grahame, R., Billings, R., Laurence, M., Marks, V., and Wood, P. J. (1974) Ann. rheum. Dis., 33, 536 (Tissue gold levels after chrysotherapy)

HENDERSON, W. J., AND GRIfFITHS, K. (1972) 'Shadow casting and replication' in 'Principles and Techniques of Electron Microscopy', ed. M. A. Hayat. van Nostrand, New York

JesSOP, J. D., Vernon-RoBERTS, B., AND HARRIS, J. (1973) Ann. rheum. Dis., 32, 294 (Effects of gold salts and prednisolone on inflammatory cells)

LAWRENCE, J. S. (1961) Ibid., 20, 341 (Studies with radioactive gold)

Norton, W. L., LeWIs, D. C., AND ZIFF, M. (1968) Arthr. and Rheum., 11, 436 (Electron-dense deposits following injection of gold sodium thiomalate and thiomalic acid)

Persellin, R. H., AND ZifF, M. (1966) Ibid., 9, 57 (The effect of gold salts on lysosomal enzymes of the peritoneal macrophage)

Poole, A. R., Hembry, R. M., Dingle, J. T., Pinder, I., Ring, E. F. J., And Cosh, J. (1974) Ann. rheum. Dis., 33, 405 (Extracellular release of cathepsin from cells in human normal and rheumatoid synovial membrane)

Silverberg, D. S., KidD, E. G., SchnitKa, AND Ulan, R. A. (1970) Arthr. and Rheum., 13, 812 (Gold nephropathy. A clinical and pathologic study)

SPeCtOR, W. G. (1969) Int. Rev. exp. Pathol., 8, 1 (The granulomatous inflammatory exudate)

Strunk, S. W., AND ZIFF, M. (1970) Arthr. and Rheum., 13, 38 (Ultrastructural studies on the passage of gold thiomalate across the renal glomerular capillary wall)

ZIFF, M. (1964) Ann. rheum. Dis., 24, 103 (Some immunologic aspects of the connective tissue diseases) 